IRA-International Journal of Management \& Social Sciences

ISSN 2455-2267; Vol.04, Issue 02 (2016)

Pg. no. 303-313

Institute of Research Advances

http://research-advances.org/index.php/RAJMSS

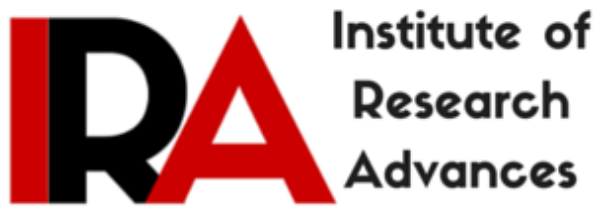

\title{
Performance Evaluation of Karnataka Vikas Grameena Bank towards Priority Sector Lending in Karnataka
}

\author{
Dr. Y. G. Baligatti \\ Associate Professor \\ KRCES Degree College, Bailhongal, India. \\ Shilpa Danappanavar \\ Research Scholar \\ Department of Commerce \\ RanichannammaUniversity,Balagavi, India.
}

Type of Review: Peer Review

DOI: http://dx.doi.org/10.21013/jmss.v4.n2.p1

\section{How to cite this paper:}

Baligatti, Y., \& Danappanavar, S. (2016). Performance Evaluation of Karnataka Vikas Grameena Bank towards Priority Sector Lending in Karnataka. IRA-International Journal of Management \& Social Sciences (ISSN 2455-2267), 4(2), 303-313. doi:http://dx.doi.org/10.21013/jmss.v4.n2.p1

(C) Institute of Research Advances

\section{(c)) BY-NC}

This work is licensed under a Creative Commons Attribution-Non Commercial 4.0 International License subject to proper citation to the publication source of the work.

Disclaimer: The scholarly papers as reviewed and published by the Institute of Research Advances (IRA) are the views and opinions of their respective authors and are not the views or opinions of the IRA. The IRA disclaims of any harm or loss caused due to the published content to any party. 


ABSTRACT
Rural Banking in India refers to a set up of financial institutions for the economic
improvement of rural poor in rural areas. The Karnataka Vikas Grameena Bank is the one of the
leading RRBs in Karnataka and has occupied an unique place in the multiagency approach applied to
provide agricultural and rural credit in rural areas of Karnataka. The KVG Bank has the front runner
in catering to the needs of the farmers, traders, rural artisans, Professionals, self-employed,
contractors and all other sections of the society.
In this paper an attempt is made to evaluate the role of the Karnataka Vikas Grameena Bank
towards priority sector lending in Karnataka, through the parameters like disbursement of loan to
various priority sectors like Agriculture, allied Activities, SSI units and Trade or Services. The study
reported that, the KVG Bank has provided highest loan to agriculture as compare to other sector of
the rural area and playing the significant role towards the development of agriculture sector. Further
it is noted that the priority sector advances of the bank to allied activities is insignificant reflecting its
utter negligence of allied activities.

Keywords: Disbursement of loans, Priority Sectors, Non Priority Sectors.

\section{Introduction:}

Rural India comprises 73 percent of the country's population, but its share in the total national income is less than 45 percent. The rural sector is characterized by low income levels, poor quality of life and a weak human capital-base. ${ }^{1}$ Finance is the most important part of any development process. Now a day's Regional Rural Bank especially in rural areas

play a very significant role in the economic as well as rural development. The overall development of the economy depends to a large extent on the banking sector, as financial institutions at as suppliers of capital for production of goods and services which in turn raises income and standard of living of the people.

The Regional Rural banks were established on October, $2^{\text {nd }} 1975$. The main objectives of these banks are to provide credit and other facilities particularly to small and marginal farmers, agricultural labourers, rural artisans and small entrepreneurs so as to develop agriculture, trade, commerce, industry and other productive activities in rural areas. The rural banks bridge the credit gaps existing in the rural areas and they are supposed to be effective instruments of economic development in rural India. They will extend productive credit to the rural community and have purely rural orientation in their activity. As on 31st March, 2014 there are 57 RRBs are playing a significant role in developing agriculture and rural economy in India. The present study is concentrating on the Karnataka Vikas Grameena Bank, which is high performing RRB in Karanataka.

\section{Karnataka Vikas Grameena Bank: An Overview}

The Karnataka Vikas Grameena Bank is the one of the most leading Regional Rural Bank in Karnataka. It has emerged after the amalgamation of the four erstwhile Grameena Banks with its area of operation spread over nine districts now caters to $1 / 3 \mathrm{rd}$ of the geographical area of the state and thereby has earned the opportunity of serving a larger section of the rural population. The government has decided to restructure 49 RRBs. The committee for restructuring consisted of representative of RBI and the NABARD and the chairman of four public sector banks. The year 2005-06 is memorable due to historic event of amalgamation of erstwhile four Regional Rural Banks sponsored by Syndicate Bank in the state of Karnataka, viz., Malaprabha Grameena Bank \& Bijapur Grameena Bank (Started in the year 1976), Varada Grameena Bank \& Netravati Grameena Bank (Started in the year 1985) which were working under 9 districts amalgamated by a Government of India notification dated 12th September 2005, to form the Karnataka Vikas Grameena Bank. Thus the new bank now operates in nine districts of the state viz., Dakshina Kannada, Udupi, Uttarakannada, Haveri, Gadag, Dharwad,

\footnotetext{
${ }^{1}$ S.P.Singh, "Emerging Issues in Indian Rural Economy, Kurukshetra, Vol.58, (3), 2010, pp.3.
} 
Belgaum, Bagalkot and Bijapur. The new bank started with the organisational set up consists of a three tier system, with the Head Office being at Dharwad, nine Regional Offices at Bagalkot, Belgaum, Bijapur, Chikodi, Dharwad, Gadag, Haveri, Kumta and Mangalore and followed by 545 branches of the bank.

KVG Bank is a scheduled Bank with share capital contributed in the ratio of 50:15:35 by the Central Government, Government of Karnataka and the Sponsor Bank respectively. The Bank has a net worth of Rs. 1173.36crores at March 31 ${ }^{\text {st }}, 2014$ and is considered as one of the strongest and most vibrant RRBs in the country. The Bank is actively involved in overall development of rural areas since the very beginning. The Bank is on core banking platform and services offered by bank branches are excellent. "Customers Delight" is the motto of the Bank. On par with other commercial Banks and also new generation Banks KVG Bank has been offering a wide range of innovative products and services in tune with customer's expectations and aspirations. The upliftment of weaker sections and the down trodden has been the major agenda of the bank. Besides this the Bank has been a front runner in catering to the needs of the Farmers, Traders, Rural Artisans, Professional and selfemployed, Contractors and all sections of the society.

\section{Priority Sector Lending:}

Priority sectors are those sectors of the economy which may not get timely and adequate credit, and may be ignored because they are low income generating sectors. But for the overall and holistic development of an economy and the country - the progress of these sectors are important too, and they have been given a special status as 'priority sector', for their benefit and for banks to follow $\mathrm{RBI}$ rules and regulations with respect to priority sector lending.

The concept was properly introduced as per recommendations of Work Group of Krishnaswami committee in 1980, there after banks have been regularly issued directives on prioriy sector loans. Revision on rules/regulations has been made latest by M.V. Nair Committee in 2012.

Priority Sector Lending is an important role given by the Reserve Bank of India (RBI) to the banks for providing a specified portion of the bank lending to few specific sectors like agriculture or small scale industries. Basically this is meant for all round development of the economy apart from only focusing on the financial sector. ${ }^{2}$

Banks have also been assigned to play a greater developmental role for upliftment of rural and urban areas. The banks in India have an important responsibility of canalizing the funds with most important sectors to fulfill the predetermined objectives. ${ }^{3}$

Priority sector plays a key role in the economic development of the country. Therefore, the Central (Federal) Government of any country gives this sector priority (first preference) in obtaining loans from banks at a low rate of interest. For more than four decades, the Reserve Bank of India (RBI) has required all public and private banks to direct a fixed percentage of lending to "priority sectors," which it defines as underserved or priority areas for economic growth. Today, state-owned and private banks must make 40 percent of all loans to the priority sector, whereas foreign banks have a minimum requirement of 32 percent.

Priority sector refers to those sectors of the economy which, though viable and creditworthy, may not get timely and adequate credit in the absence of a special dispensation. Typically, priority sector loans are small value loans to farmers for agriculture and allied activities, micro and small enterprises, poor people for housing, students for education, other low income groups and weaker sections. ${ }^{4}$

\footnotetext{
${ }^{2}$ http://www.currentaffairs.gktoday.

${ }^{3}$ http://www.yourarticlelibrary.com.

${ }^{4}$ http://www.cafral.org.in.
} 
As per Reserve Bank of India, Priority sector includes the following:

a. Agriculture and Allied Activities, dairy, fishery, animal husbandry, poultry, bee-keeping and sericulture.

b. Small scale industries (including setting up of industrial estates)

c. Small road and water transport operators (owning up to 10 vehicles).

d. Small business (Original cost of equipment used for business not to exceed 20 lakh)

e. Retail trade (advances to private retail traders up to 10 lakh)

f. Professional and self-employed persons (borrowing limit not exceeding 10 lakh of which not more than Rs.2 lakh for working capital; in the case of qualified medical practitioners setting up practice in rural areas, the limits are Rs.15 lakh and Rs.3 lakh

g. respectively and purchase of one motor vehicle within these limits can be included under priority sector)

h. State sponsored organizations for Scheduled Castes/Scheduled Tribes

i. Education (educational loans granted to individuals by banks)

j. Housing [both direct and indirect - loans up to 5 Lakhs (direct loans upto Rs 10 lakh in urban/ metropolitan areas), Loans upto Rs.1 lakh and Rs.2 lakh for repairing of houses in rural/ semi-urban and urban areas respectively].

k. Consumption loans (under the consumption credit scheme for weaker sections)

1. Micro-credit provided by banks either directly or through any intermediary; Loans to self help groups(SHGs) / Non Governmental Organizations (NGOs) for on lending to SHGs

m.Loans to the software industry (having credit limit not exceeding Rs 1 crore from the banking system)

n. Loans to specified industries in the food and agro-processing sector having investment in plant and machinery up to Rs 5 crore.

o. Investment by banks in venture capital (venture capital funds/ companies registered with SEBI) ${ }^{5}$

\section{Review of Literature:}

Dr.Jasmindeep Kaur and Silony (2011) $)^{1}$ observed that priority sector advances and agricultural advances of private and public sector banks have improved manifold ,but they are still lagging behind to achieve the targets set by RBI in agriculture sector. They concluded that the performance of private sector banks in respect of all the parameters was better than that of public sector banks in priority sector lending. ${ }^{6}$ Syed Ibrahim $(2012)^{2}$ proved that RRB's are sanctioning loan to more priority sector rather than non priority sector.

We suggested that non agricultural sector helps the rural economy in many ways; keeping in this view the RRBs should enhance percentage of loan to this sector. ${ }^{7}$

\footnotetext{
${ }^{5}$ www.gktoday.com.

${ }^{6}$ Dr.Jasmindeep Kaur and Silony, "Performance Review of Commercial Banks in India with Special Reference to Priority Sector Lending- A Study of Post Reforms Era", International Journal of Multidisciplinary Research Vol.1 (1), May 2011.
}

${ }^{7}$ Dr.Syed Ibrahim.M , Role of Indian RRB's in the Priority Sector Lending", International Management Journal,vol-1,2012. 
Dr. Bimal Jaiswal\& Ms. Saloni Bhasin $(2015)^{3}$ Focused on the changing paradigm of the Indian rural economy and highlighted how Regional Rural Banks can assist in lending to Priority Sector with specially concentrated on agriculture sector. The study concludes that RRBs in India have significantly improved their lending to priority sector especially agrarian sector. The small and marginal farmers are unable to avail credit easily. ${ }^{8}$

Sumathi (2015) ${ }^{4}$ noted that Indian agriculture is one of the strong hold of the Indian economy and it accounts for 18.5 percent of the gross domestic product (GDP). Agriculture draws its significance from the fact that it has vital supply and demand links with the manufacturing sector and is a source of livelihood for the rural population of India, and it represents the backbone of rural livelihood security system. ${ }^{9}$

\section{Methodology}

The present study is based on secondary data and has been collected from the Annual Reports of various years and official records of the KVG Bank. In this paper an attempt is made to examine the Performance Evaluation of KVG Bank towards the Priority Sector Lending. The study period is confined to 9 years from 2005-06 to 2013-14. In order to analyze the data, growth rate and various statistical tools like Mean, Correlation and ' $t$ ' Test are used through EXCEL and SPSS software.

\section{Results and Discussion:}

\subsection{Disbursement of Loan to Priority and Non priority Sector:}

Priority Sector lending includes lending to those sectors that impact large sections of the population, the weaker sections and the sectors which are employment-intensive such as agriculture, and tiny and small enterprises. With a view to providing more credits to the segments under priority sector, RRBs are required to achieve a target of $60 \%$ of their outstanding advances for priority sector advances of which at least $25 \%$ (i.e. $15 \%$ of the total advances) are to be made to weaker sections of the society w.e.f. 2003-04. The Reserve Bank of India has revised Priority Sector Lending (PSL) norms for Regional Rural Banks. As per the new norms the PSL target has increased to $75 \%$ of total outstanding advances from the earlier $60 \%{ }^{10}$ It is implemented from Jan $1^{\text {st }} 2016$. The information relating to priority and non priority sector advances of KVG Bank is presented in table-1.

\footnotetext{
${ }^{8}$ Dr. Bimal Jaiswal\& Ms. Saloni Bhasin, “An Analysis of Priority Sector Lending By Regional Rural Banks- With Special Reference to India. Agriculture Sector," Acme Intellects International Journal of Research in Management, Social Sciences \& Technology, Vol- 9, ( 9 ),2015.

9 Sumathi .N.C,"Institutional Finance for Agricultural Finance in Karnataka," Global Journal for Research Analysis, vol-4, (3), 2015.

${ }^{10} \mathrm{http}: / / \mathrm{www}$. rbi.com.
} 
Table -1

Disbursement of Loan to Priority and Non priority Sector

(Amount of Rupees is in crores.)

\begin{tabular}{|c|c|c|c|c|c|}
\hline Year & $\begin{array}{c}\text { Total Loan } \\
\text { disbursement }\end{array}$ & $\begin{array}{c}\text { Priority } \\
\text { Sector }\end{array}$ & $\begin{array}{c}\text { \% to Total } \\
\text { Loans }\end{array}$ & $\begin{array}{c}\text { Non- } \\
\text { Priority } \\
\text { Sector }\end{array}$ & $\begin{array}{c}\text { \%to total } \\
\text { Loans }\end{array}$ \\
\hline $2005-06$ & 845.21 & 647.81 & 76.64486 & 197.4 & 23.35514 \\
\hline $2006-07$ & 1100.19 & 859.1 & 78.08651 & 241.09 & 21.91349 \\
\hline $2007-08$ & 1275.15 & 1009.04 & 79.13108 & 266.11 & 20.86892 \\
\hline $2008-09$ & 1053.41 & 737.51 & 70.01168 & 315.9 & 29.98832 \\
\hline $2009-10$ & 1527.07 & 990.52 & 64.86409 & 536.55 & 35.13591 \\
\hline $2010-11$ & 2177.83 & 1452.61 & 66.69988 & 725.22 & 33.30012 \\
\hline $2011-12$ & 2942.03 & 2141.85 & 72.80177 & 800.18 & 27.19823 \\
\hline $2012-13$ & 3321.9 & 2568.85 & 77.33074 & 753.05 & 22.66926 \\
\hline $2013-14$ & 3560.48 & 2936.95 & 82.48747 & 623.53 & 17.51253 \\
\hline Mean & 1978.14 & 1482.693 & 74.22868 & 495.4478 & 25.77132 \\
\hline
\end{tabular}

Source: Annual Reports of KVG Bank.

Table - 1 reveals that the loan provided by the KVG Bank to priority sector has showing an increasing tend ranging from 647.81 crores (2005-06) to 2936.95 crores 2013-14) with an average of 1482.69 crores. It is also observed that the share of advances of priority sector to the total lending is in the range of $76 \%$ to $82 \%$ with an average of $74.23 \%$ over the study period. It is evident that the KVG Bank has achieved the target of PSL lending norms laid down by the RBI and also bank has made extra effort to reach additional target of the priority sector to improve the weaker sections of the rural society.

Further it is also witnessed that the disbursement of loan to Non -priority sector is showing an increasing trend from 197.4 crores (2005-06) to 623.53crores (2013-14) with an average share of priority sector to total lending is $25.77 \%$ over the study period. It is important to observed from the table the loans issued to priority sector constitute more percentages than the loan provided to non priority sector.

A two sample ' $t$ '- test was performed to determine whether the disbursement of priority sector loans significantly differs from the disbursement of non- priority sector loans by the KVG Bank.

\section{The hypothesis framed as follows:}

$\mathrm{H}_{0}$ : There is no difference in performance between the Priority Sector Loans and Non-Priority Sector Loans.

$\mathrm{H}_{1}$ : There is a difference in performance between the Priority Sector Loans and Non-Priority Sector Loans. 
Table-2

\begin{tabular}{|l|r|r|r|}
\hline t-Test: Two-Sample Assuming Unequal Variances & & \\
\hline & & & \\
\hline Mean & Priority Sector & Non-Priority Sector & \\
\hline Variance & 1482.693333 & 495.4477778 & \\
\hline Observations & 729721.2964 & 58559.24154 & \\
\hline & 9 & & \\
Hypothesized Mean Difference & 0 & & \\
\hline Df & 9 & & \\
\hline t Stat & 3.335846359 & & \\
\hline $\mathrm{P}(\mathrm{T}<=\mathrm{t})$ one-tail & 0.004358796 & & \\
\hline $\mathrm{t}$ Critical one-tail & 1.833112923 & & \\
\hline $\mathrm{P}(\mathrm{T}<=\mathrm{t})$ two-tail & 0.008717592 & & \\
\hline $\mathrm{t}$ Critical two-tail & 2.262157158 & & \\
\hline
\end{tabular}

Table-2 provides the result that there is strong evidence that (' $\mathrm{t}$ ' is $>2.262157158$ ), $\mathrm{H}_{0}$ is rejected. Hence there is a difference in performance between the disbursements of priority sector loans and the Non-Priority Sector Loans by the KVG Bank.

\subsection{Disbursement of Loan to Agriculture and Allied activities by the KVG Bank:}

Agriculture is the basic growth engine of Indian Economy. Agriculture accounts for nearly 18 percent of Gross Domestic Product and provides employment to around 65percent of the rural work force. ${ }^{11}$ Even though agriculture is the backbone of the Indian economy, the growth rate of agriculture is low compare to service and industry sector. Along with the agriculture allied activities like Animal husbandry Poultry Farming and Dairy Farming etc are contributing significantly to the rural economy. The KVG Bank is taking care of these sectors by providing loans. Table-1 exhibits the year wise loans provided for Agriculture and Allied activities.

${ }^{11}$ Gadhavi.B.K. and Vekariya.S.B, “ Financial Performance of RRBs in Saurashtra Region of Gujarat, Journal of Rural Development,vol.33,(1),2014. 
Table-3

\section{Disbursement of loan for Agriculture and Allied Activities}

(Amount of Rupees is in crores)

\begin{tabular}{|c|c|c|c|c|c|c|c|}
\hline Year & $\begin{array}{c}\text { Priority } \\
\text { Secotr }\end{array}$ & $\begin{array}{c}\text { Agricultu } \\
\text { re }\end{array}$ & $\begin{array}{c}\text { \% } \\
\text { increase } \\
\text { over the } \\
\text { previous } \\
\text { year }\end{array}$ & $\begin{array}{c}\text { share of } \\
\text { Agriculture } \\
\text { to total } \\
\text { priority } \\
\text { sector }\end{array}$ & $\begin{array}{c}\text { Allied } \\
\text { Activities }\end{array}$ & $\begin{array}{c}\text { share of } \\
\text { increase } \\
\text { over the } \\
\text { previous } \\
\text { year }\end{array}$ & $\begin{array}{c}\text { Allied } \\
\text { activities to } \\
\text { total } \\
\text { priority } \\
\text { sector }\end{array}$ \\
\hline $2005-06$ & 647.81 & 428.4 & & 66.13 & 7.3 & - & 1.13 \\
\hline $2006-07$ & 859.1 & 632.19 & 47.57 & 73.59 & 13.51 & 85.07 & 1.57 \\
\hline $2007-08$ & 1009.04 & 786.38 & 24.39 & 77.93 & 9.55 & -29.31 & 0.95 \\
\hline $2008-09$ & 737.51 & 516.26 & -34.35 & 70.00 & 5.18 & -45.76 & 0.70 \\
\hline $2009-10$ & 990.52 & 755.49 & 46.34 & 76.27 & 25.12 & 384.94 & 2.54 \\
\hline $2010-11$ & 1452.61 & 982.04 & 29.99 & 67.61 & 19.14 & -23.81 & 1.32 \\
\hline $2011-12$ & 2141.85 & 1493.79 & 52.11 & 69.74 & 39.8 & 107.94 & 1.86 \\
\hline $2012-13$ & 2568.85 & 1757.89 & 17.68 & 68.43 & 52.65 & 32.29 & 2.05 \\
\hline $2013-14$ & 2936.95 & 2016.01 & 14.68 & 68.64 & 69.89 & 32.74 & 2.38 \\
\hline Mean & 1482.69 & 1040.94 & 26.25 & 70.93 & 26.90 & 68.01 & 1.61 \\
\hline
\end{tabular}

Source: Official Records from the KVG Bank.

Table- 3 exhibits that; the loan provided by the KVG Bank to agriculture is showing an increasing trend over the study period. The disbursement of loan to agriculture has increased from Rs. 428.4crores (2005-06) to Rs.2016.01 crores (2013-14). It is witnessed that during the period 2008-09 there was a negative growth of disbursement of loan to agriculture (-34.35percent). This shall be attributed to the fact that the bank could not accomplish its service area plan as there was general recessionary trend in the market and also due to the fact that farmers who were not benefited under the Agricultural Debt Waiver and Debt Relief Scheme, 2008 did not come forward for renewing existing loans or availing fresh finance. Then onwards there is a sizeable increase in the growth rate of loan to agriculture reflecting an average of 26.27 percent over the study period. In terms of percentage of loan to agriculture to total priority sector advances, it is ranging from $67 \%$ to $78 \%$ with an average of $71 \%$ over the study period. From the above, it is evident that there is significant improvement in the disbursement of priority sector advances especially to agricultural sector. It is also observed that the disbursement of loan to allied activities is showing an increasing trend from 7.3 crores (2005-06) to 70 crores (2013-14) with an average of 27 crores over the study period. It is interesting to witness that the share of allied activities in total priority sector lending is insignificant which is ranging from $0.70 \%$ to $1.86 \%$ with an average of $1.61 \%$. It is a reflection of the utter negligence of bank towards distribution of loan towards allied activities.

Further In order to test whether the disbursement of agricultural loans has the linear relationship with the loan issued to allied activities, the CORRELATION tool was performed. The result is furnished in the Table-4. 
Table - 4

\begin{tabular}{|c|c|c|}
\hline & Agriculture & Allied Activities \\
\hline Agriculture & 1 & \\
\hline Allied Activities & 0.9689916 & 1 \\
\hline
\end{tabular}

The disbursement of loan to agriculture and loan to allied activities of KVG Bank is very strong positive correlation. The linear correlation co-efficient is 0.9689916 which is close to +1 . This means that the demand for agricultural loan increases the demand for the allied activities but the bank is lagging far behind to fulfill the financial needs of agriculture.

\subsection{Disbursement of Loan to Other Priority Sectors by the KVG Bank:}

KVG Bank is extending its loan service to other priority sectors like Small Scale Industries (SSIs), Trades and Services. Here Finance to Small Scale Industries includes finance to any person providing inputs to or marketing the output of artisans, village and cottage industries, handlooms and to cooperatives of producers in this sector.

Finance to Trade or Services includes here small business, retail trade, professional or self-employed persons, small road and water transport operators and other services enterprises etc. The following table gives information regarding disbursement of loan to SSI sectors, Trade/Services by the KVG Bank.

Table-5

Disbursement of Loan to Other Priority Sectors by the KVG Bank

(Amount of Rupees is in crores.)

\begin{tabular}{|l|r|c|c|r|r|r|r|}
\hline \multicolumn{1}{|c|}{ Year } & $\begin{array}{c}\text { Priority } \\
\text { Secotr }\end{array}$ & SSI & $\begin{array}{c}\text { \% increase } \\
\text { over the } \\
\text { previous } \\
\text { year }\end{array}$ & $\begin{array}{c}\text { share of } \\
\text { SSI to } \\
\text { total } \\
\text { priority } \\
\text { sector }\end{array}$ & $\begin{array}{c}\text { Trade/Ser } \\
\text { vices }\end{array}$ & $\begin{array}{c}\text { \% } \\
\text { increase } \\
\text { over the } \\
\text { previous } \\
\text { year }\end{array}$ & $\begin{array}{c}\text { share of } \\
\text { Trade/serv } \\
\text { ices to total } \\
\text { priority } \\
\text { sector }\end{array}$ \\
\hline $2005-06$ & 647.81 & 24.73 & & 3.82 & 187.38 & & 28.92515 \\
\hline $2006-07$ & 859.1 & 26.31 & 1.58 & 3.06 & 187.09 & -0.29 & 21.77744 \\
\hline $2007-08$ & 1009.04 & 73.67 & 180.01 & 7.30 & 139.44 & -47.65 & 13.81908 \\
\hline $2008-09$ & 737.51 & 44.11 & -40.12 & 5.98 & 171.96 & 32.52 & 23.31629 \\
\hline $2009-10$ & 990.52 & 62.63 & 41.99 & 6.32 & 147.28 & -24.68 & 14.86896 \\
\hline $2010-11$ & 1452.61 & 88.88 & 41.91 & 6.12 & 362.55 & 215.27 & 24.95852 \\
\hline $2011-12$ & 2141.85 & 135.05 & 51.95 & 6.31 & 473.21 & 110.66 & 22.09352 \\
\hline $2012-13$ & 2568.85 & 105.38 & -21.97 & 4.10 & 652.93 & 179.72 & 25.41721 \\
\hline $2013-14$ & 2936.95 & 123.01 & 16.73 & 4.19 & 728.1 & 75.17 & 24.79102 \\
\hline Mean & 1482.69 & 75.97 & 34.01 & 5.24 & 338.88 & 67.59 & 22.22 \\
\hline
\end{tabular}

Source: Official Records from the KVG Bank.

Table -5 determinates that disbursement of advances to SSI has showing an increasing trend ranging from 24.7 percent (2005-06) to 123percent (2013-14) with an average of 76percent over the study period. It is also observed that the share of advances of SSI to total priority sector lending is in 
the range of 3\%to $6.3 \%$ with an average of $5.24 \%$ over the study period. From the above it is evident that the share of SSI in total priority sector lending is very meager that reveals the inadequate attention of the bank towards SSI lending.

Further it is also witnessed that the disbursement of loan to trade / services is showing an increasing trend from 187.3 croes(2005-06) to 728.1 crores (2013-14) with an average of 339 crores over the study period. The share of trade / service to total priority sector lending is in the range of $14.8 \%$ to $28 \%$ with an average of $22.2 \%$ over the study period. From the above it is evident that the bank has made positive efforts to meet the financial needs of small business and self employed persons.

\section{Findings of the Study:}

The KVG Bank one of the leading Regional Rural Bank in Karnataka and front runner in meeting the financial needs of rural mass. The evaluation of the role of KVG Bank towards public sector lending reveals the following:

1. The share of priority sector advances to the total lending of the bank has reached more than the PSL target fixed by the RBI (average-74.23\%).

2. There is a stagnant improvement in disbursement of non priority sector advances to total lending (average-25.77\%).

3. There is significant improvement in the disbursement of priority sector advances of the bank especially to agriculture sector (average $-70.93 \%$ ).

4. The share of allied activities in total priority sector lending of the bank is insignificant (1.61\%) reflecting the utter negligence of bank in meeting the financial needs of allied activities.

5. The share of advance of SSI to total priority sector is very meager (5.25\%) reflecting inadequate attention of the bank towards SSI lending.

6. The share of advances of Trade/Services to total priority sector lending is around $22 \%$ that reveals the consistent effort made by the bank in meeting the financial needs of business and self-employed persons.

\section{Conclusions and suggestions:}

The KVG Bank is playing a key role in disbursement of priority sector advances. There is significant improvement in lending to priority sector especially to agriculture sector, which is the backbone of our economy and the credit needs of small and marginal farmers have met. The bank is also making consistent efforts to meet the credit needs of trade and service activities in rural areas and contributing towards the overall growth of economy. But the bank is utterly neglected the credit needs of allied activities which supporting to agricultural activities and enhances the income of rural population. Hence it is suggested to more financial assistance to allied activities. Further it is needed to give attention to meet the credit needs of SSI, as they are playing a crucial role in providing the employment to the rural people and they increase in their income.

\section{References:}

1. Bandyopadhyay, (2015), Rural Banking, Macmillan Publisher, India.

2. Chug.A.C, (2012), Rural Banking Operations, (Indian Institute of Banking and Finance),Taxmann Publication,pp-4.

3. Bimal Jaiswal\& Saloni Bhasin, (2015), An Analysis of Priority Sector Lending By Regional Rural Banks- With Special Reference to India. Agriculture Sector, Acme Intellects International Journal of Research in Management, Social Sciences \& Technology, Vol- 9, (9).

4. Gadhavi.B.K. and Vekariya.S.B, (2014), Financial Performance of RRBs in Saurashtra Region of Gujarat, Journal of Rural Development, vol.33, (1). 
5. Jasmindeep Kaur and Silony, (2011), Performance Review of Commercial Banks in India with Special Reference to Priority Sector Lending- A Study of Post Reforms Era, International Journal of Multidisciplinary Research Vol.1 (1).

6. Singh S P, (2010), Emerging Issues in Indian Rural Economy, Kurukshetra, Vol.58, (3), pp.3.

7. Sumathi .N.C, (2015), Institutional Finance for Agricultural Finance in Karnataka, Global Journal for Research Analysis, vol-4, (3).

8. Syed Ibrahim, (2012), Role of Indian RRB's in the Priority Sector Lending, International Management Journal, vol-1.

9. http://www.currentaffairs.gktoday.

10. http://www.yourarticlelibrary.com.

11. http://globalpolicy.iipcollaborative.org.

12. http://www. rbi.org.in.

13. http://www.kvgb.com. 